\title{
Evaluation of polyherbal methionine and choline in feedlot rations for lambs
}

\author{
J.R. Bárcena-Gama1, J.A. Martínez-Aispuro"\#, G.D. Mendoza-Martínez², J.L. Cordero-Mora", \\ M.T. Sánchez-Torres ${ }^{1}$, J.L. Figueroa-Velasco ${ }^{1}$ \& M.A. Ayala-Monter ${ }^{3}$ \\ ${ }^{1}$ Programa de Ganadería Colegio de Postgraduados, Campus Montecillo, Texcoco, Estado de México, México. \\ ${ }^{2}$ Departamento de Producción Agrícola y Animal, Universidad Autónoma Metropolitana, Ciudad de México, México. \\ ${ }^{3}$ Facultad de Medicina Veterinaria y Zootecnia, Universidad Autónoma de Guerrero. Cuajinicuilapa, Guerrero, México.
}

(Submitted 13 February 2020; Accepted 10 March 2020; Published 11 October 2020)

\author{
Copyright resides with the authors in terms of the Creative Commons Attribution 4.0 South African Licence. \\ See: http://creativecommons.org/licenses/by/4.0/za \\ Condition of use: The user may copy, distribute, transmit and adapt the work, but must recognise the authors and the South African \\ Journal of Animal Science.
}

\begin{abstract}
Requirements of lambs for choline and methionine have not been clearly established, but because of their metabolic relationship, the availability of these two nutrients may affect protein synthesis and energy balance. Therefore, a trial was carried out to evaluate the effect on productive performance and blood metabolites of including methionine and choline from polyherbal mixtures in finishing lamb diets. Forty Hampshire x Suffolk lambs weighing $26.9 \pm 2.8 \mathrm{~kg}$ were used for a 45-day experiment. The treatments were arranged as a $2 \times 2$ factorial, in which the factors were dietary supplementation with herbal methionine and choline at two levels $(0 \%$ and $0.4 \%$ of dry matter (DM)). The treatments had no effects on the lambs' productive variables (daily feed intake, average daily gain, and feed to gain ratio), carcass characteristics and lipid metabolites $(P>0.05)$. The results indicated that the inclusion of polyherbal mixtures containing methionine, choline and their combination at $0.4 \%$ of DM in finishing lamb diets showed no benefits in productive response or in blood metabolites related to lipid metabolism.
\end{abstract}

Keywords: amino acid, lipid metabolites, productive performance, ruminally protected, vitamin \#Corresponding author: alfredo_aispuro@yahoo.com

\section{Introduction}

Methionine is one of two limiting amino acids for protein synthesis in growing lambs, especially when a diet is high in ruminally degradable protein (Nolte et al., 2004; El-Tahawy et al., 2015). Under this condition, Osorio et al. (2013) and Lapierre et al. (2009) suggested that microbial protein that is synthesized in the rumen must be complemented with ruminally undegradable protein or protected methionine (RPM). Thus, the source and quantity of dietary protein determine the availability of essential amino acids for animals (Ali et al., 2009).

Addition of RPM to the diet of lambs increased the intake and digestibility of DM (Ali et al., 2009; ElTahawy et al., 2015). This supplementation had beneficial effects on performance in the finishing period (Imik \& Gunlu, 2011; El-Tahawy \& Ismaeil, 2013; El-Tahawy et al., 2015), which might be interpreted as indicating that methionine requirements are high in the last stage of growth (Abdelrahman et al., 2003).

However, part of the supplemented methionine can be converted to choline (Pinotti et al., 2002; NRC, 2007). In most forms, dietary choline is readily degraded in the rumen (Baldi \& Pinotti, 2006). But sources of ruminally protected choline (RPC) are rarely included in the diet of lambs. Although the requirements for choline have not been established (NRC, 2007), there is evidence that finishing lambs respond to the addition of RPC (Bryant et al., 1999; Li et al., 2015; Martinez'l et al., 2019). Because methylation needs may be so high that methionine is used to provide methyl groups, this may lead to methionine deficiency, thus reducing its availability for protein synthesis and limiting animal growth.

Organic farming is restricting the use of synthetic compounds such as chloride choline, which is used in the manufacture of RPC or rumminally protected synthetic amino acids. Therefore, natural alternative supplements that could replace synthetic products at a low cost while maintaining productive performance have been evaluated in rations for ruminants (Gutierrez et al., 2019; Martinez et al., 2019; Mendoza et al., 2019). Because choline and methionine are interrelated owing to the methylation process (Pinotti et al., 2002; Martinov et al., 2010) and because of the importance of methionine as a limiting amino acid for lamb 
growth (NRC, 2007), the objective of this trial was to evaluate the effect of supplemented methionine and choline from polyherbal mixtures in finishing diets on productive performance and lipid metabolism of lambs.

\section{Material and Methods}

All experimental procedures were performed according to the recommendations by the International Guiding Principles for Biomedical Research Involving Animals (CIOMS, 2012) and the Standards For Ethics, Biosafety and Animal Wellbeing of the Colegio de Postgraduados, Mexico, according to the Official Mexican Standard NOM-062-ZOO, 1999 (SAGARPA, 2001). The experiment was conducted in the sheep facilities at the experimental farm at the Colegio de Postgraduados, Montecillo, State of Mexico (98 $48^{\prime}$ ' 27" W; 19 $48^{\prime}$ $23 " \mathrm{~N}$ ). The climate is temperate and semi-arid, with an average annual temperature of $15.9{ }^{\circ} \mathrm{C}$, infrequent frosts, $686 \mathrm{~mm}$ average annual rainfall, and an average altitude of $2241 \mathrm{~m}$ (García, 2004).

Forty Hampshire x Suffolk lambs weighing $26.9 \pm 2.8 \mathrm{~kg}$ were used for a 45 -day experiment. The lambs were housed in individual cages equipped with single feeders and nipple drinkers. Lambs were dewormed (Chlorantel, $20 \mathrm{mg} / \mathrm{kg}$ bodyweight (BW) orally) and vaccinated against Clostridium chauvoei, Clostridium septicum, Clostridium novyi, Clostridium sordelli, Clostridium perfringes, Pasterella multocida type A, Pasterella multocida type D and Pasterella haemolytica (Bobact $8,2.0 \mathrm{~mL} /$ animal). Feed was offered at $08 \mathrm{~h} 00$ and $15 \mathrm{~h} 00$. Water and feed were provided ad libitum. Lambs had eight days to adapt to the diets.

The lambs were allocated to one of four treatments, which were arranged as a $2 \times 2$ factorial, in which the factors were dietary supplementation with herbal methionine and choline at two levels $(0 \%$ and $0.4 \%$ of DM). OptiMethione $\AA^{\circledR}$ and BioCholine Powder ${ }^{\circledR}$ were provided by Nuproxa Mexico (Querétaro, México). BioCholine is a polyherbal mixture, which contains Achyrantes aspera, Trachyspermum ammi, and Andrographis paniculata, whereas OptiMethione contains Trigonella foenumgraecum and Allium sativa. Natural choline conjugates were analysed by high-performance thin-layer chromatography (HPTLC) with lecithin as standard, and methionine was determined with HPLC (high-performance liquid chromatography) in the certified laboratory of Indian Herbs Specialities Pvt. Ltd. India. The BioCholine contained $1.6 \%$ of the natural conjugated form of choline such as phosphatidylcholine and equivalents, and OptiMethionine contained $2.8 \%$ methionine. In this experiment, synthetic lysine was added to the diet to maintain an adequate balance between the amino acids, that is, lysine to methionine ratio. The experimental diets were formulated for a daily gain of $300 \mathrm{~g} / \mathrm{d}$ (NRC, 2007) (Table 1).

The crude protein in the diets was determined with the macro Kjeldahl method (AOAC, 2005). Calcium and phosphorus were assessed by atomic absorption spectrophotometry (Karl et al., 1979) with a Perkin Elmer 4000 Model (Series Lambda 2, Perkin Elmer Inc., Norwalk, CT, USA). Acid detergent fibre was estimated with the Van Soest et al. (1991) procedure.

Average daily feed intake (ADFI), average daily gain (ADG), feed to gain ratio (FGR), and final body weight (FBW) were recorded. Back fat thickness and chop area were measured with a real-time ultrasound (Silva, 2005) Sonovet 600 (Medison, Inc., Cypress, California, USA) with a 7.5 MHz transducer between the 12th and 13th ribs, on days 1 and 45 of the experiment. On the last day of the experiment, blood samples (5 $\mathrm{mL}$ ) (preprandial at 08h00) were collected from the jugular vein by puncturing it with vacutainer tubes without anticoagulant (BD vacutainer), and immediately refrigerated at $4{ }^{\circ} \mathrm{C}$. The blood samples were centrifuged (Sigma 2-16 k, Germany) at $3500 \mathrm{~g}$ for 15 minutes to obtain blood serum, which was stored in Eppendorf tubes and stored in a freezer (Sanyo MDF-436, USA) at $-20{ }^{\circ} \mathrm{C}$ until analysis. In each sample, the concentration of total cholesterol (enzymatic oxidase-peroxidase method), glucose (enzymatic method), total protein (Biuret method), albumin (green bromocresol method), and high- and low-density lipoproteins (enzymatic method) were determined with kits from Spinreact (Barcelona, Spain).

Data were analysed as a completely randomized design with a $2 \times 2$ factorial arrangement, with four treatments and ten replicates, taking each lamb as an experimental unit. Shapiro-Wilk and Levene's tests were used to check for normality and homogeneity of variance. Data were analysed with the GLM procedure and Tukey's test $(P \leq 0.05)$ was used to compare treatment means (SAS Institute Inc., Cary, North Carolina, USA). Initial bodyweight was used as a covariate. 
Table 1 Experimental diets for lambs fed polyherbal mixtures with choline and methionine

\begin{tabular}{|c|c|c|c|c|}
\hline \multirow{2}{*}{ Ingredient (\%) } & \multicolumn{4}{|c|}{ Treatments } \\
\hline & Control & Methionine & Choline & $\begin{array}{l}\text { Methionine+ } \\
\text { Choline }\end{array}$ \\
\hline Corn grain & 55.28 & 55.28 & 55.28 & 55.28 \\
\hline Soybean meal & 23.13 & 22.73 & 22.73 & 22.33 \\
\hline Lysine $^{1}$ & 1.10 & 1.10 & 1.10 & 1.10 \\
\hline Herbal methionine ${ }^{2}$ & 0.00 & 0.40 & 0.00 & 0.40 \\
\hline Herbal choline ${ }^{3}$ & 0.00 & 0.00 & 0.40 & 0.40 \\
\hline Cane molasses & 4.00 & 4.00 & 4.00 & 4.00 \\
\hline Alfalfa hay & 10.05 & 10.05 & 10.05 & 10.05 \\
\hline Oat straw & 5.00 & 5.00 & 5.00 & 5.00 \\
\hline Calcium carbonate & 0.24 & 0.24 & 0.24 & 0.24 \\
\hline Sodium chloride & 0.20 & 0.20 & 0.20 & 0.20 \\
\hline Mineral premix ${ }^{4}$ & 1.00 & 1.00 & 1.00 & 1.00 \\
\hline \multicolumn{5}{|c|}{ Nutrient composition calculated (dry matter basis) } \\
\hline Metabolizable energy (Mcal/kg) & 2.90 & 2.90 & 2.90 & 2.90 \\
\hline Crude protein (\%) & 19.00 & 18.90 & 18.70 & 18.85 \\
\hline Ruminal undegradable protein (\%) & 7.52 & 7.52 & 7.52 & 7.52 \\
\hline Calcium (\%) & 0.50 & 0.50 & 0.50 & 0.50 \\
\hline Phosphorus (\%) & 0.46 & 0.46 & 0.46 & 0.46 \\
\hline Acid detergent fibre (\%) & 15.05 & 15.05 & 15.05 & 15.05 \\
\hline \multicolumn{5}{|c|}{ Determined nutrient composition (dry matter basis) } \\
\hline Crude protein $(\%)$ & 18.85 & 18.96 & 18.48 & 18.79 \\
\hline Calcium (\%) & 0.78 & 0.84 & 0.73 & 1.11 \\
\hline Phosphorus (\%) & 0.54 & 0.49 & 0.53 & 0.52 \\
\hline Acid detergent fibre (\%) & 14.15 & 14.26 & 14.70 & 14.54 \\
\hline
\end{tabular}

${ }^{1}$ Ajipro-L Ajinomoto 40\% L-lysine, ${ }^{2}$ Optimehion, ${ }^{3}$ Biocholine, ${ }^{4}$ Mineral premix: phosphorus $17.5 \%$, alcium $6.5 \%$, sodium $6.5 \%$, sulphur $2 \%$

\section{Results and Discussion}

None of the productive variables and carcass characteristics was affected by dietary supplementation of RPC, RPM and in combination $(P>0.05)$ (Table 2). It is possible that polyherbal methionine had little impact on the flow of estimated duodenal methionine $(1 \%)$ and, because of the types of ingredients incorporated in the ration, the synthesis of microbial protein allowed all rations to supply adequate methionine $(17 \mathrm{~g} / \mathrm{d})$. In addition, the diets were high in protein $(19 \%)$. In studies in which responses to RPM were reported, the dietary crude protein concentration was lower than 15.7\% (Abdelrahman et al., 2003; Imik \& Gunlu, 2011; El-Tahawy et al., 2015). Moreover, Obeidat et al. (2008) suggested that methionine supplementation is not likely to produce beneficial effects on nutrient digestibility, performance and carcass characteristics of lambs fed with a high-performance diet. Rodríguez-Guerrero et al. (2018) also found that the addition of herbal RPM had no effects on bodyweight, DM intake and digestibility. They explained that the lack of response in lamb growth with supplemental RPM might have been caused by the low lysine content in the basal diet, which resulted in an inadequate ratio of lysine to methionine. In this work the authors assumed that the increased level of lysine in the diet would improve the balance between lysine and methionin. However, the supplementation regimes did not produce a beneficial response. 
Table 2 Effect of polyherbal choline and methionine on lamb performance and carcass characteristics

\begin{tabular}{|c|c|c|c|c|c|c|}
\hline \multirow[b]{2}{*}{ Performance measure } & \multicolumn{4}{|c|}{ Treatment } & \multirow[b]{2}{*}{ SEM } & \multirow[b]{2}{*}{$P$-value } \\
\hline & Control & Methionine & Choline & $\begin{array}{c}\text { Methionine } \\
+ \text { choline }\end{array}$ & & \\
\hline Initial BW,kg & 27.00 & 27.03 & 26.88 & 26.54 & 0.474 & 0.94 \\
\hline Final BW, kg & 43.47 & 43.88 & 43.15 & 43.47 & 0.641 & 0.98 \\
\hline$A D G, \mathrm{~kg} / \mathrm{d}$ & 0.343 & 0.351 & 0.338 & 0.345 & 0.009 & 0.97 \\
\hline DM intake, kg/d & 1.503 & 1.532 & 1.559 & 1.471 & 0.026 & 0.81 \\
\hline Feed: gain ratio & 4.47 & 4.46 & 4.59 & 4.46 & 0.094 & 0.94 \\
\hline Back fat, mm & 3.55 & 3.77 & 3.66 & 3.37 & 0.093 & 0.56 \\
\hline Initial chop area, $\mathrm{mm}^{2}$ & 775 & 748 & 721 & 721 & 6.92 & 0.97 \\
\hline Final chop area, $\mathrm{mm}^{2}$ & 1141 & 1154 & 1137 & 1170 & 17.7 & 0.97 \\
\hline
\end{tabular}

ADG: average daily gain; BW: bodweight; DM intake: dry matter intake

For the response to a ruminally protected amino acid to be expressed, lambs fed the basal diet must have limited duodenal flow in relation to the requirement. In Imik and Gunlu (2011), RPM supplementation increased the ADG significantly, and the estimated flow of methionine in the control treatment was $2.4 \mathrm{~g} / \mathrm{d}$. Although several experiments in lambs indicated that the response was positive when incorporating RPM in $0.20 \%$ to $0.33 \%$ of the diet (Imik \& Gunlu, 2011; El-Tahawy \& Ismaeil, 2013; El-Tahawy et al., 2015), supplementation at up to $0.4 \%$ may have null or negative effects (Obeidat et al., 2008; Ali et al., 2009). Therefore, the methionine flux from a basal ration should be estimated and not generalized by dietary concentration. In addition to the response to RPM being quadratic, Abdelrahman and Hunaiti (2008) found that supplementation with $2 \mathrm{~g} / \mathrm{d}$ RPM produced the greatest effects on ADG, FGR and carcass yield when they evaluated doses of 0 to $4 \mathrm{~g} / \mathrm{d}$.

The amount and quality of amino acids that reach the small intestine are influenced by the synthesis of microbial protein and the quantity of ruminally undegradable protein provided in the diet (Gao et al., 2015). Thus, the types and levels of dietary protein have important effects on metabolizable essential amino acids (Ali et al., 2009). Ruminally undegradable protein in this experiment was $7 \%$ of DM, which is considered a high concentration (NRC, 2007). Therefore, no methionine deficiency was shown, as occurs in diets with high ruminally degradable protein sources (Nolte et al., 2004). Further, fermentable carbohydrates were able to provide carbon skeletons for the synthesis of microbial protein (Lapierre et al., 2009) and allowed for adequate expression of growth by the lambs (El-Tahawy \& Ismaeil, 2013).

Polyherbal choline intake (approximately $6 \mathrm{~g} / \mathrm{d}$ ) had no effect on the productive variables and carcass characteristics. Similar results were observed by Godinez-Cruz et al. (2015) and Rodriguez-Guerrero et al. (2018) with $4 \mathrm{~g} / \mathrm{d}$. However, Martinez et al. (2019) found that supplementation with approximately 5, 10 and $15 \mathrm{~g} / \mathrm{d}$ of herbal RPC produced linear responses in daily gain, FBW, feed conversion, blood glucose, and blood phosphatidylcholine as the level of dietary herbal choline increased. Concurrently, total protein, globulins, and low-density lipoproteins showed a quadratic response. There was also evidence that the inclusion of plant feed additives containing conjugates of choline improved milk yield, fertility and important health indiators in first-lactation cows, which helped to lower the repalcement rate (Gutierrez et al., 2019). Li et al. (2015) found production traits and meat quality exhibited quadratic responses to supplementation with RPC, with the best response being with $0.25 \%$ RPC in the lamb diets and with negative effects at $0.75 \%$ on ADG (representing 2.6 and $7.8 \mathrm{~g} / \mathrm{d}$ of RPC, respectively). Bryant et al. (1999) observed a $10 \%$ increase in ADG by adding $0.25 \%$ choline to the diet (equivalent to $2 \mathrm{~g} / \mathrm{d}$ of RPC). However, there was no difference among other levels $(0,0.5$, and $1.0 \%)$ of RPC. The degree of protection of commercial RPC products is not known precisely and varies in choline content (Kung et al., 2003; Jayaprakash et al., 2016). In addition, the physiological needs for methylation may be covered by methionine (Pinotti et al., 2002; Martinov et al., 2010), thus making it difficult to establish a recommendation for RPC and herbal products, yet performance data indicated (Martínez-Aispuro et al., 2019) that it should not exceed a daily dose of $4 \mathrm{~g} / \mathrm{d}$ of RPC.

In spite of the metabolic relationship of choline and methionine as donors of methyl groups, no advantage was found in supplementing these nutrients together. It has been suggested that methionine may spare choline utilization in dairy cattle (Soltan et al., 2012) and dairy sheep (Tsiplakou et al., 2017). Supplementation with herbal choline plus herbal methionine improved milk production and $4 \%$ fat-corrected milk in supplemented cows (Mendoza et al., 2019). However, the positive response to the supplemented 
combination of choline and methionine in diets for dairy ewes may be present only when conditions of highnutrient demands and low-protein diets are combined (Piepenbrink \& Overton, 2003).

The addition of choline and methionine to the diet had no detectable effect on the amount of subcutaneous fat in the chop area, which is consistent with other experiments with levels of $0.25-0.75 \%$ RPC (Bryant et al., 1999; Li et al., 2015). However, in lactating sheep, the combination of choline and methionine increased the amount of fat in milk (Tsiplakou et al., 2017). Previous work showed the lipotropic effect of both nutrients in dairy cattle (Piepenbrink \& Overton, 2003; Osorio et al., 2014). Several mechanisms of action mediated by carnitine synthesis have been discussed (Bryant et al., 1999) and their effects on the deposition of fat (Eklund et al., 2005).

In the present experiment, dietary supplementation with RPM and RPC did not affect the concentrations of cholesterol, high-density lipoproteins, glucose, proteins and globulins in blood plasma $(P$ $>0.05)$ (Table 3). Only the concentration of albumins $(P<0.004)$ was increased by combining RPM and RPC (Table 3). Other studies in sheep showed that the inclusion of RPC at levels of $0.25-0.75 \%$ did not modify the concentration of cholesterol and triglycerides in plasma (Bryant et al., 1999; Baldi \& Pinotti, 2006). However, Imik and Gunlu (2011) found that adding $0.20 \%$ of protected methionine to the diet for fattening lambs increased the concentration of triglycerides and reduced the concentration of glucose.

Table 3 Effect of polyherbal mixtures with choline and methionine on lamb blood metabolites

\begin{tabular}{|c|c|c|c|c|c|c|}
\hline \multirow{2}{*}{ Serum constituent } & \multicolumn{4}{|c|}{ Treatment } & \multirow{2}{*}{ SEM } & \multirow{2}{*}{$P$-value } \\
\hline & Control & Methionine & Choline & Methionine + choline & & \\
\hline Cholesterol, mg/dL & 54.30 & 49.78 & 55.62 & 61.24 & 2.118 & 0.28 \\
\hline $\mathrm{HDL}, \mathrm{mg} / \mathrm{dL}$ & 28.35 & 24.41 & 31.92 & 35.57 & 1.814 & 0.15 \\
\hline LDL, mg/dL & 19.35 & 25.10 & 17.92 & 17.99 & 1.165 & 0.34 \\
\hline Glucose, mg/dL & 83.76 & 85.85 & 88.70 & 89.56 & 1.779 & 0.66 \\
\hline Protein, g/dL & 5.84 & 6.10 & 6.46 & 6.30 & 0.123 & 0.34 \\
\hline Albumins, $\mathrm{g} / \mathrm{dL}$ & $3.02^{\mathrm{ab}}$ & $2.71^{\mathrm{b}}$ & $2.88^{\mathrm{b}}$ & $3.25^{\mathrm{a}}$ & 0.057 & 0.004 \\
\hline Globulins, g/dL & 2.83 & 3.39 & 3.57 & 3.06 & 0.083 & 0.14 \\
\hline
\end{tabular}

HDL: high-density lipoproteins; LDL: low-density lipoproteins

Although the requirements of choline and methionine for lambs have not been well established (NRC, 2007), the conditions in which their supplementation is required must be identified to potentiate the productive performance in relation to the demands for methylation and for microbial protein synthesis and the interrelation of these metabolites in the organism.

\section{Conclusion}

The inclusion of polyherbal mixtures containing either methionine or choline or in combination, at a concentration of $0.4 \% \mathrm{DM}$, in finishing lamb diets provided limited if any benefit in productive response or serum metabolites indicative of lipid metabolism.

\section{Authors' Contributions}

JRBG, JAMA, GDMM, JLCM, TSTE, JLFV, MAAM were responsible for the design and execution of the project. All co-authors participated in management and discussion of the results, statistical analysis and writing of the manuscript.

\section{Conflict of Interest Declaration}

Authors declare that there is no conflict of interest regarding the publication of this article.

\section{References}

Abdelrahman, M. \& Hunaiti, D., 2008. The effect of dietary yeast and protected methionine on performance and trace minerals status of growing Awassi lambs. Livest. Sci. 115(2), 235-241. https://doi.org/10.1016/j.livsci.2007.07.015

Abdelrahman, M.M., Numan, A.M., Rayyan, A.L., Faisal, T., Awarded, A. \& Alazzeh, A.Y., 2003. The effect of dietary levels of zinc-methionine on the performance of growing Awassi lambs. Pak. J. Biol. Sci. 6(11), 979-983. https://doi.org/10.3923/pjbs.2003.979.983 
Ali, C.S., Sharif, M., Nisa, M., Javaid, A., Hashmi, N. \& Sarwar, M., 2009. Supplementation of ruminally protected proteins and amino acids: Feed consumption, digestion and performance of cattle and sheep. Int. J. Agric. Biol. 11(4), 477-482.

AOAC, 2005. Official methods of analysis (18th ed.). Association of Official Analytical Chemists, Inc., Washington DC, USA.

Baldi, A. \& Pinotti, L., 2006. Choline metabolism in high-producing dairy cows: Metabolic and nutritional basis. Can. J. Anim. Sci. 86(2), 207-212. https://doi.org/10.4141/A05-061

Bryant, T.C., Rivera, J.D., Galyean, M.L., Duff, G.C., Hallford, D.M. \& Montgomery, T.H., 1999. Effects of dietary level of ruminally protected choline on performance and carcass characteristics of finishing beef steers and on growth and serum metabolites in lambs. J. Anim. Sci. 77(11), 2893-2903. https://doi.org/10.2527/1999.77112893x

CIOMS, 2012. International guiding principles for biomedical research involving animals. Council for International Organizations of Medical Sciences. Accessed October 2019. https://issuu.com/aaalac/docs/igp2012

Eklund, M., Bauer, E., Wamatu, J. \& Mosenthin, R., 2005. Potential nutritional and physiological functions of betaine in livestock. Nutr. Res. Rev. 18(1), 31-48. https://doi.org/10.1079/NRR200493

El-Tahawy, A.S. \& Ismaeil, A.M., 2013. Methionine-supplemented diet increases the general performance and value of Rahmani lambs. Iranian J. Appl. Anim. Sci. 3(3), 513-520.

El-Tahawy, A.S., Ismaeil, A.M. \& Ahmed, H.A., 2015. Effects of dietary methionine-supplementation on the general performance and economic value of Rahmani lambs. J. Anim. Sci. Adv. 5(10), 1457-1466.

Gao, W., Chen, A., Zhang, B., Kong, P., Liu, C. \& Zhao, J., 2015. Rumen degradability and post-ruminal digestion of dry matter, nitrogen and amino acids of three protein supplements. Asian Australas. J. Anim. Sci. 28(4), 485. https://doi.org/10.5713/ajas.14.0572

García, E., 2004. Modifications to the system Köppen climate classification (5th ed.). Book series number 6 . Institute of Geography, Autonomous University of Mexico.

Godinez-Cruz, J., Cifuentes-López, O., Cayetano, J., Lee-Rangel, H., Mendoza, G., \& Vázquez, A. \& Roque, A., 2015. Effect of choline inclusion on lamb performance and meat characteristics. J. Anim. Sci. 93 (Suppl. 3), 766.

Gutierrez, A., Gutierrez, A., Sanchez, C. \& Mendoza, G. D., 2019. Effect of including herbal choline in the diet of a dairy herd: A multiyear evaluation. Emir. J. Food Agric. 31(6), 477-481.

Imik, H. \& Gunlu, A., 2011. Effects of sodium bicarbonate, polyethylene glycol and methionine added to rations with sorghum (Sorghum vulgare) in fattening lambs on growth performance, wool quality and some blood biochemical markers. Rev. Med. Vet. 162(8), 432-439.

Jayaprakash, G., Sathiyabarathi, M., Robert, M.A. \& Tamilmani, T., 2016. Rumen-protected choline: A significance effect on dairy cattle nutrition. Vet. World 9(8), 837-841. https://doi.org/10.14202/vetworld.2016.837-841

Karl, R.F., McDowell, L.R., Miles, P.H., Wilkinson, N.S., Funk, J.D. \& Conrad, J.H., 1979. Methods of mineral analysis of plant and animal tissues (2nd ed.). Gainesville, FL, USA. University of Florida.

Kung, L., Putnam, D.E. \& Garrett, J.E., 2003. Comparison of commercially available rumen-stable choline products. J. Dairy Sci. 86 (Suppl. 1), 275.

Lapierre, H., Ouelle, D.R. \& Dopel, L., 2009. Do you feed protein or amino acids to make milk? Adv. Dairy Technol. 21, 175-189.

Li, H., Wang, H., Yu, L., Wang, M., Liu, S., Sun, L. \& Chen, Q., 2015. Effects of supplementation of rumen-protected choline on growth performance, meat quality and gene expression in longissimus dorsi muscle of lambs. Arch. Anim. Nutr. 69(5), 340-350. https://doi.org/10.1080/1745039X.2015.1073001

Martinez-Aispuro, J.A., Mendoza, G.D., Cordero-Mora, J.L., Ayala-Monter, M.A., Sánchez-Torres, M.T., FigueroaVelasco, J.L., Vázquez-Silva, G. \& Gloria-Trujillo, A., 2019. Evaluation of an herbal choline feed plant additive in lamb feedlot rations. R. Bras. Zootec. 48, e20190020. http://dx.doi.org/10.1590/rbz4820190020

Martinov, M.V., Vitvitsky, V.M., Banerjee, R. \& Ataullakhanov, F.I., 2010. The logic of the hepatic methionine metabolic cycle. Biochim. Biophys. Acta. 1804(1), 89-96. https://doi.org/10.1016/j.bbapap.2009.10.004

Mendoza, G.D., Oviedo, M.F., Pinos, J. M., Lee-Rangel, H.A., Vázquez, A., Flores, R., Perez, F., Roque, A. \& Cifuentes, O., 2019. Milk production in dairy cows supplemented with herbal choline and methionine. Rev. Fac. Cien. Agrarias. 1(1), 1-12

Nolte, J.E., Ferreira, A.V., Nolte, N.K., Petersen, M.K. \& Hallford, D.M., 2004. Methionine, at least one branched-chain amino acid, are limiting in lambs. Proc. West Sec. Amer. Soc. Anim. Sci. 55, 421-423.

NRC, National Research Council, 2007. Nutrient Requirements of Small Ruminants (7th ed.). National Academy Press, Washington DC, USA

Obeidat, B.S., Abdullah, A.Y., Awawdeh, M.S., Kridli, R.T., Titi, H.H. \& Qudsieh, R.I., 2008. Effect of methionine supplementation on performance and carcass characteristics of Awassi ram lambs fed finishing diets. Asian Australas. J. Anim. Sci. 21(6), 831. https://doi.org/10.5713/ajas.2008.70536

Osorio, J.S., Ji, P., Drackley, J.K., Luchini, D. \& Loor, J.J., 2013. Supplemental Smartamine M or MetaSmart during the transition period benefits postpartal cow performance and blood neutrophil function. J. Dairy Sci. 96(10), 62486263. https://doi.org/10.3168/jds.2012-5790

Osorio, J.S., Trevisi, E., Ji, P., Drackley, J.K., Luchini, D., Bertoni, G. \& Loor, J.J., 2014. Biomarkers of inflammation, metabolism, and oxidative stress in blood, liver, and milk reveal a better immunometabolic status in peripartal cows supplemented with Smartamine $M$ or MetaSmart. J. Dairy Sci. 97(12), 7437-7450. https://doi.org/10.3168/jds.2013-7679

Piepenbrink, M. \& Overton, T., 2003. Liver metabolism and production of cows fed increasing amounts of rumenprotected choline during the periparturient period. J. Dairy Sci. 86(5), 1722-1733. https://doi.org/10.3168/jds.S0022-0302(03)73758-8 
Pinotti, L., Baldi, A. \& Dell'Orto, V., 2002. Comparative mammalian choline metabolism with emphasis on the highyielding dairy cow. Nutr. Res. Rev. 15(2), 315-331. https://doi.org/10.1079/NRR200247

Rodriguez-Guerrero, V., Lizarazo, A. C., Ferraro, S., Suárez, N., Miranda, L. A. \& Mendoza, G. D., 2018. Effect of herbal choline and rumen-protected methionine on lamb performance and blood metabolites. S. Afr. J. Anim. Sci. 48(3), 427-434. http://dx.doi.org/10.4314/sajas.v48i3.3

SAGARPA, 2001. Norma Oficial Mexicana NOM-062-ZOO-1999, Especificaciones técnicas para la producción, cuidado y uso de los animales de laboratorio. Secretaría de Agricultura, Ganadería, Desarrollo Rural, Pesca y Alimentación. Diario Oficial de la Federación. 75, 113-160.

Silva, S.R., Gomes, M.J., Días-da-Silva, A., Gil, L.F. \& Azevedo, J.M., 2005. Estimation in vivo of the body and carcass chemical composition of growing lambs by real-time ultrasonography. J. Anim. Sci. 83(2), 350-357. https://doi.org/10.2527/2005.832350x

Soltan, M.A., Mujalli, A.M., Mandour, M.A. \& Abeer, M.E.S., 2012. Effect of dietary rumen protected methionine and/or choline supplementation on rumen fermentation characteristics and productive performance of early lactating cows. Pak. J. Nutr. 11(3), 221.

Tsiplakou, E., Mavrommatis, A., Kalogeropoulos, T., Chatzikonstantinou, M., Koutsouli, P., Sotirakoglou, K., Labrou, N. \& Zervas, G., 2017. The effect of dietary supplementation with rumen-protected methionine alone or in combination with rumen-protected choline and betaine on sheep milk and antioxidant capacity. J. Anim. Physiol. Anim. Nutr. 101(5), 1004-1013. https://doi.org/10.1111/jpn.12537

Van Soest, P.J., Robertson, J.B. \& Lewis, B.A., 1991. Methods for dietary fibre, neutral detergent fibre, and nonstarch carbohydrates in relation to animal nutrition. J. Dairy Sci. 74(10), 3583-3597. https://doi.org/10.3168/jds.S00220302(91)78551-2 